\title{
HUBUNGAN PERSEPSI PENCEGAHAN DAN PERAWATANKELUARGA DENGAN KUALITAS HIDUP PADA LANSIA BERPENYAKIT KRONIS DI WILAYAH RW 06 KELURAHAN JOMBANG KECAMATAN CIPUTAT KOTA TANGERANG SELATAN TAHUN 2015
}

\author{
Rina Nur Setyaningsih ${ }^{1}$, Diah Ratnawati ${ }^{2}$ \\ S1 Keperawatan Fakultas Ilmu-ilmu Kesehatan \\ Universitas Pembangunan Nasional "Veteran" Jakarta \\ Jln. Limo Raya, Depok \\ E-mail : Rinanurs04@gmail.com
}

\begin{abstract}
Prevention and care of the elderly is to maintain the health of the elderly with regard food consumed, accompany and help the elderly carry out their activities and taking care of personal hygiene to maintain hygiene and optimal health that requires the support and attention of the family themselves. Quality of life in elderly quality is the functional condition of elderly in optimal conditions, so that they can enjoy their old age meaningful, happy and useful. The purpose of this research is to identify whether there is any relationship perception of prevention and treatment of families with the quality of life in older adults with chronic diseases. This study used cross sectional design, which used 81 samples using purposive sampling technique. The results obtained are elderly with < 65 years (58\%) were female (63\%) low education (58\%) to stay with family (74\%) and suffered from asthma (28\%) for $\geq 3$ months (56,8\%). Perception prevention families with chronically ill elderly poor (55.6\%) and family care punn poor (50.6\%), thus affecting the quality of life in older adults with chronic diseases. Researchers suggest to families to better prevention and treatment to improve the quality of life of the elderly.
\end{abstract}

Keywords: Prevention and treatment of the family, quality of life in older adults with chronic diseases.

\section{PENDAHULUAN}

Menua adalah suatu proses menghilangnya secara perlahan kemampuan jaringan untuk memperbaiki diri atau mengganti diri dan mempertahankan struktur dan fungsi normalnya sehingga tidak dapat bertahan dan memperbaiki kerusakan yang di derita (Darmojo dan Martono, 1994 dalam Nugroho, 2012).

Di Indonesia tahun 2000 diperkirakan jumlah dan porporsi segmen penduduk di atas 60 tahun adalah 17.767.709 juta $(7,97 \%)$ dari jumlah penduduk, dan pada tahun 2005 jumlah ini di perkirakan meningkat menjadi 19.936 .895 juta $(8,48 \%)$, pada tahun 2010 jumlah lansia semakin meningkat menjadi 
23.992.513 juta $(9,77 \%)$ dan di perkirakan pada tahun 2020 jumlah lansia akan semakin meningkat menjadi 28.882 .879 juta $(11,34 \%)$ (Nugroho, 2012). Hasil survey Badan Pusat Statistik (BPS) dalam (Nugroho, 2012) jumlah lansia di Indonesia sebanyak 17.717.880 jiwa atau sebanyak 23.992.552 jiwa dan pada tahun 2020 diperkirakan menjadi 28.8822.879 jiwa atau 11,34\%. Jadi, hal diatas dapat disimpulkan bahwa tiap tahun terjadi peningkatan jumlah pada lansia. Peningkatan jumlah lansia tersebut juga harus diiringi dengan peningkatan kesehatan karena pada usia tua akan terjadi proses menua yaitu proses yang mengubah seorang dewasa sehat menjadi seorang yang frail (lemah atau rentan) dengan berkurangnya sebagian besar cadangan sistem fisiologis dan meningkatnya kerentanan terhadap berbagai penyakit dan kematian secara eksponensial. (Sudoyo, 2009)

Prebiakusis umumnya terjadi setelah umur 65 tahun, terjadi dibawah umur 65tahun sebesar 5-20\%, sedangkan diatas umur 65tahun terjadi sekitar $60 \%$. Sistem penglihatan: lensa lebih suram, kornea lebih berbentuk skeris, hilangnya daya akomodasi, data Badan Pusat Statistik dalam Data dan Informasi Kementrian Kesehatan RI (2013) terdapat $4,75 \%$ lansia mengalami katarak, sistem musculoskletal. (Nugroho, 2012).

Berdasarkan beberapa penelitian terkait tentang hubungan persepsi pencegahan dan perawatan keluarga dengan kualitas hidup pada lansia berpenyakit kronis yang terjadi, disertai data-data lansia berdasarkan hasil wawancara dengan kader kesehatan dan ketua RW 06 di Kelurahan Jombang. RW 06 terdiri dari 3 RT yang memiliki jumlah populasi lansia yaitu sebanyak 102 lansia dan beragamnya jenis penyakit kronis yang diderita lansia di RW 06, sebagian besar lansia memiliki riwayat asma, maag, rheumatik, hipertensi, diabetes mellitus, jantung. Pada hasil wawancara dengan beberapa lansia yang mengatakan bahwa mereka sering mengalami rasa khawatir akan kondisi kesehatannya. Uraian beberapa data diatas, peneliti tertarik untuk meneliti hubungan persepsi pencegahan dan perawatan keluarga dengan kualitas hidup pada 
lansia berpenyakit kronis. Hal tersebut sangat penting karena saat ini kualitas hidup pada lansia menurun disebabkan oleh kurangnya persepsi keluarga dalam pencegahan dan perawatan pada lansia dengan penyakit kronis. Penelitian ini untuk mengidentifikasi ada atau tidaknya hubungan persepsi pencegahan dan perawatan keluarga dengan kualitas hidup pada lansia berpenyakit kronis di wilayah RW 06 Kelurahan Jombang.

Kualitas hidup suatu kajian yang melibatkan berbagai sudut pandang yang tidak hanya melibatkan status fungsional dan beratnya gejala tetapi juga menyangkut pemahaman tentang perkembangan mental (psikologi), sosiokultural, etika, dan spiritual (Luccenotte, 2003). Kualitas Hidup yang baik sama seperti hidup dengan kehidupan yang berkualitas tinggi.

Menurut WHO 1994 dalam (Bangun, 2008), kualitas hidup didefinisikan sebagai persepsi individu sebagai laki-laki atau wanita dalam hidup, ditinjau dari konteks budaya dan sistem nilai dimana mereka tinggal, dan berhubungan dengan standar hidup, harapan, kesenangan, dan perhatian mereka. Hal ini merupakan konsep tingkatan, terangkum secara kompleks mencakup kesehatan fisik, status psikologis, tingkat kebebasan, hubungan sosial, dan hubungan kepada karakteristik lingkungan mereka.

Peranan keluarga dalam memelihara dan meningkatkan kesehatan setiap anggota keluarga serta dalam menjamin keberhasilan pelayanan keluarga amat penting sekali, karena keluarga memang punya arti dan kedudukan tersendiri dalam masalah kesehatan (Azwar, 2007).

Kualitas hidup lansia merupakan suatu komponen yang kompleks dimana mencakup tentang usia harapan hidup, kepuasan dalam kehidupan, kesehatan psikis dan mental, fungsi kognitif, kesehatan dan fungsi fisik, pendapatan, kondisi tempat tinggal, dukungan sosial, dan jaringan sosial. Di Indonesia para lansia biasanya tinggal bersama anaknya terutama lansia yang sudah tidak mendapatkan penghasilan sendiri (Nawi, 2010). 
METODE PENELITIAN

Desain penelitian menggunakan desain cross sectional. Data penelitian diperoleh dengan berdasarkan survey dengan menggunakan kuisioner. Penelitian ini dilaksanakan pada bulan Mei sampai dengan bulan Juli tahun 2015 di wilayah RW 06 Kelurahan Jombang.Variabel dependent adalah variabel respon atau outcome. Sebagai variabel respon berarti variabel ini akan muncul sebagai akibat dari manipulasi suatu variabel independen. Variabel dependen disini yaitu kualitas hidup pada lansia berpenyakit kronis.

\section{HASIL PENELITIAN}

Dibawah ini akan dibahas mengenai hasil mulai dari analisis univariat dan bivariat:

\section{Analisa Univariat}

a) Usia Responde

\begin{tabular}{ccc} 
& Tabel 1 \\
\hline Usia & Jumlah & Persentase \\
\hline$<65$ tahun & 47 & 58,0 \\
\hline$\geq 65$ tahun & 34 & 42,0 \\
\hline Total & 81 & 100,0 \\
\hline
\end{tabular}

Tabel 1 hasil penelitian didapat mayoritas responden berusia $<65$ tahuh. Hasil tersebut sesuai dengan teori menurut Azizah (2011) mengelompokkan lanjut usia menjadi usia dewasa muda (Elderly Adulhood) 18 atau 29-25 tahun, usia dewasa penuh (Middle Years) atau maturitas 25-60 tahun atau 65 tahun, lanjut usia (Geriatric Age) lebih dari 65 tahun atau 70 tahun yang di bagi lagi dengan 70-75 tahun (Young Old), 75-80 tahun (Old), lebih dari 80 (Very Old).

Rendahnya lanjut usia yang berusia < 65 tahun dapat disebabkan rendahnya angka Umur Harapan Hidup (UHH) di Indonesia masih rendah yaitu 65,8 tahun. Rendahnya UHH di Indonesia ini disebabkan beberapa hal antara lain rendahnya akses pelayanan kesehatan, rendahnya akses air bersih, rendah gizi balita, mewabahnya penyakit menular. Penelitian tersebut dapat disimpulkan bahwa semakin tinggi usia lansia akan berpotensi mengalami peningkatan kesehatan. Karena pada lansia akan terjadi 
proses menua yaitu proses yang mengubah seorang dewasa sehat menjadi seorang yang lemah atau rentan.

\section{b) Jenis Kelamin}

Tabel 2

\begin{tabular}{ccc}
\hline $\begin{array}{c}\text { Jenis } \\
\text { kelamin }\end{array}$ & Jumlah & Persentase \\
\hline Laki-laki & 30 & 37,0 \\
\hline Perempuan & 51 & 63,0 \\
\hline Total & 81 & 100,0 \\
\hline
\end{tabular}

Tabel 2 hasil penelitian didapat mayoritas responden berjenis kelamin perempuan. Jadi sebagian besar responden berjenis kelamin perempuan sebanyak 51 responden $(63,0 \%$.). Hasil penelitian ini sejalan dengan hasil penelitian yang dilakukan oleh Sutikno (2011) yaitu dengan hasil proporsi jumlah lansia berjenis kelamin perempuan lebih besar yaitu $64,4 \%$ dan jumlah lansia yang berjenis kelamin laki-laki sebesar 36,6\%. Penelitian ini tidak sejalan dengan penelitian Yuliati (2014) yaitu dengan hasil jumlah populasi lansia berjenis kelamin lakilaki $5,2 \%$ dan perempuan $12,4 \%$.

Kesenjangan pada proporsi jenis kelamin dapat terjadi karena pada pengambilan data penelitian di RW
06 Kelurahan Jombang Kecamatan Ciputat dengan jumlah populasi sebesar 102 orang dan pengambilan sampel 81 jiwa dan pengambilan sampel diambil berdasarkan pada suatu pertimbangan tertentu yang dibuat oleh peneliti sendiri berdasarkan kriteria eksklusi dan kriteria inklusi. Penelitian yang dilakukan oleh Sutikno (2011) tentang hubungan antara fungsi keluarga dan kualitas hidup pada lansia tidak menemukan hubungan yang secara statistik signifikan antara jenis kelamin dengan kualitas hidup pada lansia. Pada penelitian ini menyebutkan bahwa lansia berjenis kelamin perempuan cenderung mempunyai kualitas hidup yang lebih buruk dibandingkan laki-laki.

c) Pendidikan

Tabel 3

\begin{tabular}{ccc}
\hline $\begin{array}{c}\text { Pendidikan } \\
\text { Responden }\end{array}$ & Jumlah & Persentase \\
\hline $\begin{array}{c}\text { Tinggi } \\
\text { (SMA,D3,S1) }\end{array}$ & 47 & 58,0 \\
\hline $\begin{array}{c}\text { Rendah } \\
\text { (SD,SMP) }\end{array}$ & 34 & 42,0 \\
\hline Total & 81 & 100,0 \\
\hline
\end{tabular}

Tabel 3 menunjukkan bahwa sebagian besar responden memiliki tingkat pendidikan tinggi sebanyak 47 orang dengan persentase $58,0 \%$, sedangkan responden dengan tingkat pendidikan 
rendah berjumlah 34 orang dengan persentase $42,0 \%$. Jadi sebagian besar responden memiliki tingkat pendidikan tinggi yaitu sebanyak $58,0 \%$. Hasil penelitian ini sejalan dengan penelitian Sutikno (2011) berdasarkan pendidikan yaitu pendidikan tingkat tinggi sebanyak 25 orang dengan persentase $61,0 \%$ dan pendidikan tingkat rendah sebanyak 16 orang dengan persentase $39,0 \%$.

Pendidikan adalah suatu kegiatan atau proses pembelajaran untuk mengembangkan atau meningkatkan kemampuan tertentu sebagai sasaran pendidikan itu dapat berdiri sendiri Notoatmodjo (2003). Pendidikan umumnya dibagi menjadi tahap seperti prasekolah, sekolah dasar, sekolah menengah, dan kemudian perguruan tinggi.

Tingkat pendidikan lansia merupakan hal terpenting dalam menghadapi masalah, semakin tinggi pendidikan seseorang, semakin banyak pengalaman hidup yang dilaluinya, sehingga akan lebih siap menghadapi masalah yang terjadi. Penelitian ini dapat disimpulkan bahwa semakin tinggi pendidikan seseorang akan berpengaruh terhadap kemampuan berfikir rasional dan menangkap informasi baru termasuk dalam menangani masalah penyakit kronis dalam diri seseorang.

\section{d) Status Pekerjaan}

Tabel 4

\begin{tabular}{ccc}
\hline $\begin{array}{c}\text { Status } \\
\text { Pekerjaan }\end{array}$ & Jumlah & Persentase \\
\hline Bekerja & 35 & 43,2 \\
\hline $\begin{array}{c}\text { Tidak } \\
\text { bekerja }\end{array}$ & 46 & 56,8 \\
\hline Total & 81 & 100,0 \\
\hline
\end{tabular}

Tabel 4 menunjukkan bahwa dari 81 responden yang diteliti terdapat 35 orang dengan persentase $43,2 \%$ yang bekerja sedangkan 46 orang dengan persentase $56,8 \%$ yang tidak bekerja. Hasil penelitian ini tidak sejalan pada penelitian Sutikno (2011) menunjukkan bahwa sampel lansia lebih banyak yang bekerja yaitu 26 orang $(63,4 \%)$ dibandingkan yang tidak bekerja yaitu 15 orang $(36,6 \%)$ menunjukkan terdapatnya hubungan yang tidak signifikasi secara statistik antara pekerjaan dengan kualitas hidup pada lansia sedangkan pada beberapa penelitian dinyatakan bahwa pekerjaan berhubungan dengan 
sosio-ekonomi dan hal ini dapat mempengaruhi kualitas hidup. Penelitian ini sejalan dengan penelitian Yenny (2006) menunjukkan bahwa lansia tidak bekerja (64\%) dan yang bekerja (36\%). Penelitian ini menunjukkan terdapatnya hubungan yang signifikan secara statistik antara pekerjaan dan kualitas hidup pada lansia. Pekerjaan adalah sesuatu yang dilakukan oleh manusia untuk tujuan tertentu yang dilakukan dengan cara yang baik dan benar. Manusia perlu bekerja untuk mempertahankan hidupnya. Dengan pekerja seseorang akan mendapatkan uang. Uang diperoleh dari hasil bekerja tersebut digunakan untuk memenuhi kebutuhan hidup.

e) Tempat tinggal

Tabel 5

\begin{tabular}{lcc}
\hline $\begin{array}{c}\text { Tempat } \\
\text { Tinggal }\end{array}$ & Jumlah & Persentase \\
\hline $\begin{array}{l}\text { Tinggal } \\
\text { bersama } \\
\text { keluarga }\end{array}$ & 60 & 74,1 \\
\hline $\begin{array}{l}\text { Tinggal } \\
\text { sendiri }\end{array}$ & 21 & 25,9 \\
\hline Total & \multicolumn{2}{c}{100,0} \\
\hline $\begin{array}{l}\text { Tabel } 5 \\
\text { sebagian }\end{array}$ & besar responden tinggal \\
bersama & keluarga yaitu sebanyak
\end{tabular}

60 orang dengan persentase $74,1 \%$ sedangkan responden yang tinggal sendiri sebanyak 21 orang dengan persentase $25,9 \%$. Jadi sebagian besar responden tinggal bersama keluarga yaitu sebanyak $74,1 \%$. Hasil penelitian ini sejalan dengan penelitian Suprapti (2007) hubungan persepsi keluarga tentang perawatan pada lansia yaitu sebagian besar dari responden menyatakan bahwa merawat lansia merupakan tanggung jawab sebagai seorang anak untuk membalas budi kepada orangtuanya karena itu mereka tidak setuju bila lansia ditempatkan di panti.

Lansia masih konsisten untuk terus mempertahankan dan mengembangkan lingkungan kehidupan yang berbasis pada konsep keluarga. Dalam pandangan responden tergambarkan bahwa lembaga keluarga-rumah dan penghuninya adalah merupakan suatu yang terindah dan bahkan semacam surga baginya. Karena dalam keluargalah, lansia dapat melaksanakan fungsi-fungsi 
normatif seperti: reproduksi, ekonomi, pendidikan, keagamaan, sosial budaya, cinta dan kasih sayang, perlindungan dan melestarikan lingkungan.

\section{f) Jenis Penyakit}

Tabel 6

\begin{tabular}{lcc}
\hline $\begin{array}{c}\text { Jenis } \\
\text { Penyakit }\end{array}$ & Jumlah & Persentase \\
\hline Asma & 23 & 28,4 \\
\hline Maag & 15 & 18,5 \\
\hline Rematik & 20 & 24,7 \\
\hline $\begin{array}{l}\text { Tekanan } \\
\text { Darah } \\
\text { Tinggi }\end{array}$ & 17 & 21,0 \\
\hline Gula & 3 & 3,7 \\
\hline Jantung & 3 & 3,7 \\
\hline Total & 81 & 100,0 \\
\hline
\end{tabular}

Tabel 6 menunjukkan bahwa berdasarkan jenis penyakit yang paling banyak diderita oleh responden adalah Asma yaitu sebanyak 23 orang dengan persentase $28,4 \%$. Kemudian data hasil menunjukkan penyakit Rematik yang diderita responden sebanyak 20 orang dengan persentase 24,7\%. Penyakit Tekanan Darah Tinggi diderita oleh 17 orang dengan persentase 21,0\% penyakit Maag sebanyak 15 orang dengan persentase $18,5 \%$ penyakit Gula dan Jantung di derita oleh 3 orang dengan persentase $3,7 \%$. Pada penelitian Yenny hubungan penyakit kronis dan kualitas hidup di dapatkan hasil Penyakit muskuloskeletal $(61,4 \%)$ dan kardiovaskuler $(51,1 \%)$ lebih banyak dialami lansia pria dibandingkan lansia wanita.

Selain itu penyakit digestif $(47,2 \%)$ dan metabolik $(29,4 \%)$ lebih banyak dialami lansia wanita dibandingkan lansia pria. Kejadian keganasan tidak banyak ditemukan baik pada lansia pria $(1,1 \%)$ maupun lansia wanita $(1,4 \%)$.

Penelitian ini dapat disimpulkan bahwa penyakit kronis mempengaruhi kualitas hidup dimensi kesehatan fisik karena dapat membatasi individu untuk melakukan aktivitas yang dianggapnya penting. Adanya penyakit kronis juga mengganggu kontrol perasaan seseorang terhadap dirinya.

\section{g) Lama Sakit}

Tabel 7

Jenis
Penyakit Jumlah Persentase




\begin{tabular}{llc}
\hline$<3$ bulan & 35 & 43,2 \\
\hline$\geq 3$ bulan & 46 & 56,8 \\
\hline Total & 81 & 100,0 \\
\hline
\end{tabular}

Tabel 7 menunjukkan bahwa berdasarkan lama sakit terlihat pada responden menderita penyakit selama $\geq 3$ bulan sebanyak 46 orang dengan persentase $56,8 \%$ sedangkan responden yang menderita penyakit selama $<3$ bulan sebanyak 35 orang dengan persentase $43,2 \%$. Pada penelitian ini 46 responden menderita penyakit lebih dari tiga bulan, hal ini disebabkan pada penelitian telah ditetapkan pada kriteria inklusi yaitu responden yang memiliki riwayat penyakit kronis.

Penyakit kronis adalah penyakit atau kondisi yang gejalanya berlangsung lebih dari tiga bulan, dan pada beberapa kasus selama kehidupan seseorang pemulihannya lambat dan terkadang tidak total. (Mckenzie, 2007) Lansia yang sakit kurang dari tiga bulan mengalami rasa khawatir yang sedang terhadap kesehatannya. Selain itu lansia yang sakit lebih dari tiga bulan mengalami rasa khawatir yang sangat besar terhadap kesehatannya.

\section{h) Penghasilan perbulan}

Tabel 8

\begin{tabular}{lll}
\hline $\begin{array}{c}\text { Penghasilan } \\
\text { Perbulan }\end{array}$ & Jumlah Persentase \\
\hline$\leq \mathrm{Rp} \mathrm{500.000}$ & 66 & 81,5 \\
\hline $\mathrm{Rp} \mathrm{500.000-}$ & 12 & 14,8 \\
$\mathrm{Rp} 1.000 .000$ & & \\
\hline$>\mathrm{Rp} 1.000 .000$ & 3 & 3,7 \\
\hline Total & 81 & 100,0 \\
\hline
\end{tabular}

Tabel 8 menunjukkan bahwa berdasarkan penghasilan perbulan responden yaitu sebagian besar responden memiliki penghasilan $\leq$ Rp 500.000 perbulan sebanyak 67 orang dengan persentase $82,7 \%$, responden dengan penghasilan $\mathrm{Rp}$ 500.000 - Rp 1.000 .000 perbulan sebanyak 12 orang dengan persentase $14,8 \%$ sedangkan responden dengan penghasilan perbulan > Rp 1.000.000 sebanyak 2 orang dengan persentase $2,5 \%$. Jadi sebagian besar responden memiliki penghasilan $\leq \mathrm{Rp}$ 500.000 yaitu $82,7 \%$. Hasil status ekonomi ini dinyatakan dalam UMR Kota Tangerang Selatan. Mayoritas responden memiliki pekerjaan, namun penghasilan 
mereka perbulan tergolong rendah (dibawah UMR Kota Tangerang Selatan).

\section{i) Persepsi pencegahan keluarga}

Tabel 9

\begin{tabular}{lcc}
\hline $\begin{array}{c}\text { Persepsi } \\
\text { Pencegahan } \\
\text { Keluarga }\end{array}$ & Jumlah & Persentase \\
\hline Kurang baik & 45 & 55,6 \\
\hline Baik & 36 & 44,4 \\
\hline Total & 81 & 100,0 \\
\hline
\end{tabular}

Tabel 9 menunjukkan bahwa berdasarkan persepsi pencegahan keluarga yang berada di RW 06 Kelurahan Jombang memiliki persepsi kurang baik tentang pencegahan pada lansia yaitu sebanyak $55,6 \%$ sedangkan $44,4 \%$ lainnya berpersepsi baik tentang pencegahan terhadap lansia. Hasil penelitian ini tidak sejalan dengan dengan penelitian Suprapti (2007) menunjukkan bahwa sebanyak 58,5\% keluarga memiliki persepsi kurang baik tentang pencegahan pada lansia dan hanya $41,5 \%$ yang berpersepsi baik. Penelitian ini dapat disimpulkan berdasarkan persepsi pencegahan keluarga di RW 06 Kelurahan Jombang sebagian besar masyarakat baik memahami tentang tindakan pencegahan yang dilakukan terhadap lansia dirumah mulai segi penyajian makanan dimana keluarga harus memperhatikan makanan yang boleh dan tidak boleh dikonsumsi lansia.

Persepsi diartikan sebagai suatu identifikasi dan interpretasi awal terhadap stimulus yang dipengaruhi oleh informasi yang diterima melalui lima panca indera yang terdiri dari penglihatan, pendengaran, perabaan, penghidu, dan pengecap. Besarnya persepsi pencegahan keluarga yang kurang baik menunjukkan bahwa sebagian besar masyarakat di kelurahan ini kurang memahami tentang pencegahan keluarga yang dilakukan terhadap lansia di rumah mulai dari segi penyajian makanan dimana keluarga kurang memperhatikan makanan yang boleh dan tidak boleh dikonsumsi lansia, keluarga membebaskan lansia makan apa saja yang lansia sukai tanpa memperhatikan dampak negatinya. Dalam hal ini sebagian besar responden berpendapat bahwa kalau mengenai makanan, keluarga juga hanya tergantung pada kesukaan 
lansia, karena itu keluarga tidak dapat melarang lansia. Keluarga juga hanya memeriksakan kesehatan lansia pada saat sakit saja.

j) Perawatan keluarga

Tabel 10

\begin{tabular}{lcc}
\hline $\begin{array}{l}\text { Perawatan } \\
\text { Keluarga }\end{array}$ & Jumlah & Persentase \\
\hline Kurang baik & 41 & 50,6 \\
\hline Baik & 40 & 49,4 \\
\hline Total & 81 & 100,0 \\
\hline
\end{tabular}

Tabel 10 menunjukkan bahwa berdasarkan perawatan keluarga yang berada di RW 06 Kelurahan Jombang memiliki perawatan keluarga yang kurang baik pada lansia yaitu sebanyak 50,6\% sedangkan $\quad 49,4 \% \quad$ lainnya perawatan keluarga yang baik terhadap lansia.

Hasil penelitian ini tidak sejalan dengan dengan penelitian Suprapti (2007) menunjukkan bahwa sebanyak 58,5\% keluarga memiliki persepsi kurang baik tentang pencegahan pada lansia dan hanya $41,5 \%$ yang berpersepsi baik. Penelitian ini dapat disimpulkan berdasarkan persepsi pencegahan keluarga di RW 06 Kelurahan
Jombang sebagian besar masyarakat baik memahami tentang tindakan perawatan yang dilakukan terhadap lansia dirumah mulai segi penyajian makanan dimana keluarga harus memperhatikan makanan yang boleh dan tidak boleh dikonsumsi lansia dan keluarga juga harus memeriksakan kesehatan lansia secara rutin.

Besarnya persepsi perawatan keluarga yang kurang baik menunjukkan bahwa sebagian besar masyarakat di kelurahan ini kurang memahami tentang pencegahan keluarga yang dilakukan terhadap lansia di rumah mulai dari segi penyajian makanan dimana keluarga kurang memperhatikan makanan yang boleh dan tidak boleh dikonsumsi lansia, keluarga membebaskan lansia makan apa saja yang lansia sukai tanpa memperhatikan dampak negatifnya. Dalam hal ini sebagian besar responden berpendapat bahwa kalau mengenai makanan, keluarga juga hanya tergantung pada kesukaan 
lansia, karena itu keluarga tidak dapat melarang lansia.

Sebagian besar dari responden menyatakan bahwa merawat lansia merupakan tanggung jawab sebagai anak untuk membalas budi kepada orang tuanya karena itu mereka tidak setuju bila lansia ditempatkan dipanti. Hal ini diperkuat dengan pernyataan Junaidi (2007) dimana di Indonesia "Extended Family" masih banyak dijumpai,terutama di pedesaan. Lansia, terutama yang tinggal di pedesaan belum mengenal panti jompo, karena masih ada anggota keluarga yang bersedia merawat mereka. Generasi muda masih menyadari bahwa mereka berkewajiban menanggung kehidupan orang tuanya. Walaupun responden mengakui bahwa perawatan dipanti lebih terjamin.

k) Kualitas hidup responden

Tabel 11

\begin{tabular}{lcc}
\hline $\begin{array}{c}\text { Kualitas } \\
\text { Hidup }\end{array}$ & Jumlah & Persentase \\
\hline Baik & 34 & 42,0 \\
\hline Kurang baik & 47 & 58,0 \\
\hline Total & 81 & 100,0 \\
\hline
\end{tabular}

Tabel 11 menunjukkan bahwa kualitas hidup pada lansia sangat kurang baik dengan persentase $58,0 \%$ sebanyak 47 orang, sedangkan kualitas hidup yang baik 34 orang dengan persentase $42,0 \%$. Penelitian ini sejalan dengan penelitian Sutikno (2011) menunjukkan ada hubungan yang secara statistik signifikan antara fungsi keluarga dengan kualitas hidup pada lansia. Fungsi keluarga yang sehat dengan kualitas hidup baik $(90,3 \%)$.

Pada penelitian ini alat bantu dalam pengambilan sampel yang peneliti gunakan yaitu menggunakan kuesioner yang dikeluarkan oleh WHO dalam pengukuran keadaan hidup seseorang, dalam hal ini peneliti menggunakan kuesioner WHOQOL-BREF. Dimana WHOQOL-BREF diperuntukkan pada responden tanpa memandang kriteria responden. Dan WHOQOL-BREF dapat digunakan untuk menilai kualitas hidup seseorang. Saat ini peneliti gunakan untuk menilai kualitas hidup geriatri. Penilaian 
menggunakan kuesioner ini memakai bantuan wawancara dalam pengisian kuesioner.

\section{Analisa Bivariat}

Analisa bivariat bertujuan untuk mengetahui hubungan antara variabel independen dengan variabel dependen. Analisa bivariat ini terdiri dari persepsi keluarga tentang tindakan pencegahan dengan kualitas hidup pada lansia berpenyakit kronis dan perawatan keluarga dengan kualitas hidup pada lansia berpenyakit kronis.

a) Persepsi keluarga tentang tindakan pencegahan pada lansia berpenyakit kronis

Tabel 12

\begin{tabular}{llllllll}
\hline Persepsi & \multicolumn{4}{c}{ Kualitas Hidup } & & \\
\cline { 2 - 6 } $\begin{array}{l}\text { Pencegahan } \\
\text { Keluarga }\end{array}$ & Baik & \multicolumn{4}{c}{$\begin{array}{l}\text { Kurang } \\
\text { baik }\end{array}$} & Total & \multicolumn{1}{c}{$\begin{array}{l}\text { P } \\
\text { value }\end{array}$} \\
\cline { 2 - 7 } & N & $\%$ & N & $\%$ & N & $\%$ & \\
\hline Baik & 24 & 53,3 & 21 & 46,7 & 45 & 100 & 0,037 \\
Kurang baik & 10 & 27,8 & 26 & 72,2 & 36 & 100 & \\
\hline Total & 34 & 42,0 & 47 & 58,0 & 81 & 100 & \\
\hline
\end{tabular}

Tabel 12 peneliti telah mengambil data menggunakan uji Chi Square pada tingkat kepercayaan CI 95\% dan $\alpha=0,05$. Hasil penelitian secara statistik menunjukkan ada hubungan antara persepsi keluarga tentang tindakan pencegahan dengan kualitas hidup pada lansia $(\mathrm{p}$-value $=0,037, \mathrm{CI}$ 95\%). Hasil analisis diperoleh pula nilai OR $(95 \% \mathrm{Cl}) 2,971(1,166-$ 7,572) artinya pencegahan yang kurang baik mempunyai peluang 2,97 kali untuk kualitas hidup baik dibanding pencegahan yang baik.

Kualitas hidup lansia merupakan suatu komponen yang kompleks, mencakup usia harapan hidup, kepuasan dalam kehidupan, kesehatan psikis dan mental, fungsi kognitif, kesehatan dan fungsi fisik, pendapatan, kondisi tempat tinggal, dukungan sosial dan jaringan sosial. Di Indonesia para lansia biasanya tinggal bersama anaknya terutama lansia yang sudah tidak mendapatkan penghasilan sendiri (Nawi, 2010).

Persepsi pencegahan keluarga yang kurang baik menunjukkan bahwa sebagian besar masyarakat di kelurahan ini kurang memahami tentang pencegahan keluarga yang dilakukan terhadap lansia di rumah mulai dari segi penyajian makanan dimana keluarga kurang memperhatikan makanan yang 
boleh dan tidak boleh dikonsumsi lansia, keluarga membebaskan lansia makan apa saja yang lansia sukai tanpa memperhatikan dampak negatifnya. Dalam hal ini sebagian besar responden berpendapat bahwa kalau mengenai makanan, keluarga juga hanya tergantung pada kesukaan lansia, karena itu keluarga tidak dapat melarang lansia. Keluarga juga hanya memeriksakan kesehatan lansia pada saat sakit saja.

b) Hubungan persepsi keluarga tentang tindakan perawatan keluarga dengan kualitas hidup pada lansia berpenyakit kronis

Tabel 13

\begin{tabular}{|c|c|c|c|c|c|}
\hline \multirow{3}{*}{$\begin{array}{l}\text { Perawatan } \\
\text { keluarga }\end{array}$} & \multicolumn{2}{|c|}{ Kualitas Hidup } & \multirow{2}{*}{\multicolumn{2}{|c|}{ Total }} & \multirow{3}{*}{$\begin{array}{l}\mathrm{P} \\
\text { value }\end{array}$} \\
\hline & $\begin{array}{l}\text { Kurang } \\
\text { baik }\end{array}$ & Baik & & & \\
\hline & N \% & $\mathrm{N} \quad \%$ & $\mathrm{~N}$ & $\%$ & \\
\hline Kurang & $28 \quad 68,3$ & $13 \quad 31,7$ & 41 & 100 & 0,020 \\
\hline $\begin{array}{l}\text { baik } \\
\text { Baik }\end{array}$ & $16 \quad 40,0$ & $24 \quad 60,0$ & 40 & 100 & \\
\hline Total & $44 \quad 54,3$ & $37 \quad 45,7$ & & 100 & \\
\hline
\end{tabular}

Tabel 13 menunjukkan bahwa peneliti telah mengambil data dengan menggunakan uji Chi Square pada tingkat kepercayaan CI $95 \%$ dan $\alpha=0,05$. Hasil penelitian secara statistik menunjukkan ada hubungan antara persepsi keluarga tentang tindakan perawatan dengan kualitas hidup pada lansia $(\mathrm{p}$-value $=0,020, \mathrm{CI}$ $95 \%)$.

Perawatan keluarga yang kurang baik menunjukkan bahwa sebagian besar masyarakat di kelurahan ini kurang memahami tentang pencegahan keluarga yang dilakukan terhadap lansia di rumah mulai dari segi penyajian makanan dimana keluarga kurang memperhatikan makanan yang boleh dan tidak boleh dikonsumsi lansia, keluarga membebaskan lansia makan apa saja yang lansia sukai tanpa memperhatikan dampak negatifnya.

\section{KESIMPULAN}

Setelah dilakukan penelitian Wilayah RW 06 Kelurahan Jombang Kecamatan Ciputat Kota Tangerang Selatan Tahun 2015, maka dapat disimpulkan sebagai berikut:

1. Gambaran karakteristik usia pada lanjut usia menunjukkan sebagian besar responden berusia $<65$ tahun (58\%), berjenis kelamin 
perempuan $(63 \%)$, berpendidikan rendah (58\%), lansia yang tinggal bersama keluarga (74\%) dan menderita penyakit asma (28\%) selama $\geq 3$ bulan $(56,8 \%)$.

2. Gambaran persepsi pencegahan keluarga dengan lansia berpenyakit kronis menunjukkan sebagian besar responden persepsi pencegahannya kurang baik $(55,6 \%)$.

3. Gambaran perawatan keluarga dengan lansia berpenyakit kronis menunjukkan sebagian besar responden memiliki perawatan keluarga yang kurang baik $(50,6 \%)$ sehingga mempengaruhi kualitas hidup pada lansia berpenyakit kronis.

4. Gambaran kualitas hidup pada lansia berpenyakit kronis menunjukkan sebagian besar yang kurang baik $(58,0 \%)$.

5. Hubungan karakteristik lansia dengan kualitas hidup pada lansia berpenyakit kronis menunjukkan sebagian besar responden berusia $<65$ tahun memiliki kualitas hidup yang kurang baik $(59,6 \%)$, berjenis kelamin perempuan memiliki kualitas hidup yang kurang baik $(51,0 \%)$, berpendidikan rendah memiliki kualitas hidup yang kurang baik $(52,9 \%)$, lansia yang tinggal bersama keluarga memiliki kualitas hidup yang kurang baik $(61,7 \%), \quad$ responden yang menderita penyakit asma dengan kualitas hidup yang kurang baik $(65,2 \%)$, dan lamanya sakit selama $\geq 3$ bulan memiliki kualitas hidup yang kurang baik $(60,9 \%)$.

6. Hubungan persepsi pencegahan keluarga dengan kualitas hidup pada lansia berpenyakit kronis. Hasil uji statistik melalui $C h i$ Square, ditemukan $\mathrm{P}$ value 0,037 yang artinya $P$ value $>0,05$, hal ini menunjukkan bahwa ada hubungan yang bermakna antara persepsi pencegahan keluarga dengan kualitas hidup pada lansia berpenyakit kronis. Hasil Odd Ratio menunjukkan nilai $\mathrm{OR}=2,971$ yang artinya bahwa responden dengan persepsi pencegahan keluarga yang kurang baik mempunyai peluang 2,971 kali lebih tinggi untuk persepsi pencegahan keluarga dibandingkan dengan responden yang persepsi pencegahan keluarga yang baik.

7. Hubungan perawatan keluarga dengan kualitas hidup. Hasil uji 
statistik melalui Chi Square, ditemukan $\mathrm{P}$ value 0,020 yang artinya $P$ value $>0,05$, hal ini menunjukkan bahwa ada hubungan yang bermakna antara perawatan keluarga dengan kualitas hidup pada lansia berpenyakit kronis. Hasil Odd Ratio menunjukkan nilai $\mathrm{OR}=3,231$ yang artinya bahwa responden dengan perawatan keluarga yang kurang baik mempunyai peluang 3,231 kali lebih tinggi untuk perawatan keluarga dibandingkan dengan responden yang perawatan keluarga yang baik.

\section{SARAN}

Berdasarkan hasil penelitian yang telah dilakukan peneliti, maka diajukan beberapa saran untuk penelitian berikutnya, yaitu:

a. Bagi Lansia

Lansia diharapkan menjaga kondisi kesehatan dengan ikut serta dalam program kesehatan lansia secara rutin.

b. Bagi Keluarga

Keluarga diharapkan dapat meningkatkan pengertian dan pemahaman keluarga terkait pencegahan dan perawatan terhadap lansia berpenyakit kronis.

c. Bagi Dinas Kesehatan

Dinas Kesehatan bisa lebih meningkatkan kembali pengetahuan keluarga terkait pencegahan dan perawatan lansia yaitu dengan melakukan penyuluhan, mendatangi rumah keluarga yang memiliki lansia agar persepsi keluarga lebih positif.

d. Bagi Profesi Keperawatan

Profesi keperawatan bisa melakukan tindakan keperawatan promotif, preventif, dan kuratif untuk mengurangi dampak penyakit kronis yang dimiliki lansia dan juga untuk mengurangi tingkat kecemasan yang dialami lansia.

e. Bagi Institusi Pendidikan Keperawatan

Institusi pendidikan keperawatan sebaiknya melakukan penelitian lanjut mengenai hubungan persepsi pencegahan dan perawatan keluarga dengan kualitas hidup pada lansia berpenyakit kronis agar lebih banyak lagi informasi yang berguna bagi perkembangan pendidikan keperawatan dan sebagai tambahan studi penelitian 
khususnya keperawatan komunitas dan gerontik.

f. Bagi penelitian selanjutnya

Peneliti merekomendasikan penelitian selanjutnya agar area penelitian yang digunakan dapat dikembangkan lagi pada beberapa tempat dengan sampel yang lebih representatif, melakukan revisi dan menambah instrumen penelitian untuk mencapai validitas dan reabilitas dengan terlebih dahulu melakukan uji coba lebih dari sekali terhadap validitas dan reabilitas, perlu mencoba menggunakan desain perbandingan misalnya membandingkan persepsi keluarga yang merawat lansia dirumah dengan persepsi keluarga yang menempatkan lansia dipanti.

\section{REFERENSI}

Adib \& Mohammad 2008, Penelitian Lansia di Perkotaan: Tinggal Bersama Keluarga Lebih Nyaman, Diakses tanggal 2 Maret 2015 , madib.blog.unair.ac.id/files/200 8/11/penelitian-lansia-di perkotaan.pdf.

Ali \& Zaidin1999, Pengantar Keperawatan Kesehatan Keluarga, Yayasan Bunga Raflesi. Depok.
Azizah \& Lilik Ma'rifatul, 2011, Keperawatan lanjut usia, Graha Ilmu, Yogyakarta.

BKKBN 2012, Delapan Fungsi Keluarga Wahana Menuju Keluarga Sejahtera, Diakses 23 April 2015 , http://www.bkkbn.go.id

Darmojo \& Boedhi 2009, Geriatri (Ilmu Kesehatan Usia Lanjut), Edisi -4,Balai Penerbit FKUI, Jakarta

Indonesia Departemen Kesehatan RI, Profil Kesehatan Indonesia, 2006, Diakses tanggal 3 Februari 2015, http://www.depkes.go.id.

Indonesia Departemen Kesehatan RI. Pedoman Pembinaan Kesehatan Lanjut Usia Bagi Petugas Kesehatan I: Kebijakan Program, diakses tanggal 4 Maret 2015, http://www.depkes.go.id

Dinas Kesehatan Kota, 2008, Data statisitik lansia, Dinkes Kota, Pekanbaru.

Effendy1998.Dasar-dasar

Keperawatan Kesehatan Masyarakat, Edisi2, EGC, Jakarta.

Friedman1998, Keperawatan Keluarga Teori dan Praktek, Edisi 3, EGC, Jakarta.

Kompas. WHO:Waspadai Ledakan Jumlah Lansia. 2012.Diakses tanggal 25 Februari 2015 (http://health.kompas/)

Linda T. 2012. Latihan Fisik dan Kualitas Hidup pada Lansia di 
Kecamatan Dimembe, Kabupaten Minahasa Utara. Diakses tanggal 25 Februari 2015

http://igenursing.weebly.com/u ploads/1/4/3/9/14390416/fix_jk u_ekin.pdf

Maryam, Rosidawati. 2012. Beban Keluarga Merawat Lansia dapat Memicu Tindakan Kekerasan dan Penelantaran Terhadap Lansia. Diakses tanggal 25 Februari 2015 (http://jki.ui.ac.id/index.php/jki/ article/download/2/2)

Siti. R, 2008, Mengenal Usia Lanjut dan Perawatannya. Salemba Medika, Jakarta.

Ns.Sri Artinawati, Skep2014,Asuhan Keperawatan Gerontik, IN MEDIA, Bogor.

Notoatmodjo S2007, Kesehatan Masyarakat Ilmu dan Seni, PT.Rineka Cipta, Jakarta.

Nugroho\&Wahyudi2008.

Keperawatan Gerontik \& Geriatrik, Edisi 3, EGC, Jakarta.

Setiadi 2007, Konsep Dan Penulisan Riset Keperawatan, Grahallmu, Yogyakarta

Setiadi, 2008, Konsep dan Proses keperawatan Keluarga. Yogyakarta : Graha Ilmu.

Stanley, Mikey 2007,Buku Ajar Keperawatan Gerontik, Edisi 2, EGC, Jakarta

Noorkasiani, 2009,Kesehatan Usia Lanjut dengan Pendekatan
Asuhan Keperawatan.

Jakarta : Salemba Medika.

Sutikno, 2011, 'Hubungan antara Fungsi Keluarga dan kualitas hidup lansia', vol.2, no.1, Januari 2011, hlm 76-78.

Sutikno2011,Hubungan antara Fungsi Keluarga dan Kualitas Hidup Lansia. Diakses Tanggal 25 Februari 2015 (http://jkiina.com/index.php/jki/article/do wnload/13/12)

Sutikno2011, 'Hubungan antara Fungsi Keluarga dan kualitas hidup lansia', vol.2, no.1, Januari 2011, hlm 60-75.

Sutikno, 2011, 'Hubungan antara Fungsi Keluarga dan kualitas hidup lansia', vol.2, no.1, Januari 2011, hlm 40-55.

Suprajitno. 2004. Asuhan Keperawatan Keluarga Aplikasi dan Praktik. Jakarta: EGC.

WHO, 2004, WHO Quality Of Life Breef, Geneva: World Health Organization.

Yenny \& Elly H, 'Prevalensi Penyakit Kronis dan Kualitas Hidup pada Lanjut Usia di Jakarta Selatan', vol.25, no.4, Oktober-Desember 2006, hlm 165.

Yenny \& Elly H, 'Prevalensi Penyakit Kronis dan Kualitas Hidup pada Lanjut Usia di Jakarta Selatan', vol.25, no.4, Oktober-Desember 2006, hlm 167-170.

Yuliati, 2014,Perbedaan Kualitas Hidup Lansia yang Tinggal di 
Komunitas dengan di

Pelayanan Sosial Lanjut

UsiaDiakses tanggal 6 Februari
2015

(https://jurnal.unej.ac.id/index.p hp/JPK/article/.../601/429) 